American J. of Engineering and Applied Sciences 5 (1): 1-8, 2012

ISSN 1941-7020

(C) 2014 R.O. Yusuf et al., This open access article is distributed under a Creative Commons Attribution

(CC-BY) 3.0 license

\title{
Greenhouse Gas Emissions: Quantifying Methane Emissions from Livestock
}

\author{
${ }^{1}$ Rafiu O. Yusuf, ${ }^{1}$ Zainura Z. Noor, ${ }^{1}$ Ahmad H. Abba, \\ ${ }^{1}$ Mohd Ariffin Abu Hassan and ${ }^{2}$ Mohd Fadhil Mohd Din \\ ${ }^{1}$ Department of Chemical Engineering, Faculty of Chemical Engineering, \\ University Technology Malaysia, 81310 Skudai, Johor Bahru, Malaysia \\ ${ }^{2}$ Department of Environmental Engineering, Faculty of Civil Engineering, \\ University Technology Malaysia, 81310 Skudai, Johor Bahru, Malaysia
}

\begin{abstract}
Problem statement: The rearing of animals for domestic consumption and export invariably lead to the production of methane as a product of digestion. This study investigated the emission of methane from Malaysian livestock between 1980 and 2008. Approach: Seven categories of animals identified were camel, buffalo, sheep, goats, horse, pigs and poultry. The estimation of methane was based on the IPCC Tier 1 and Tier 2 methods. Methane emission from cattle rose by 44\% within the period from 45.61-65.57 Gg. Results: Buffalo recorded a drop in methane emission by $54 \%$ from $17.12-7.86 \mathrm{Gg}$ while the methane emission from sheep initially rose by $350 \%$ in 1992 only to drop by another $56 \%$ by 2008 . Goats emission only declined by $17 \%$ from $1.79 \mathrm{Gg}$ in $1980-1.49 \mathrm{Gg}$ by 2008. Methane emission from horse has been consistent at around $0.14 \mathrm{Gg}$. The decreasing stock of pigs has led to a drop in methane emission from these set of animals with most of the emission coming from manure management. Conclusion: The healthy export market for poultry has seen a rise in methane emission by $274 \%$ from $2.18 \mathrm{Gg}$ in $1980-8.17 \mathrm{Gg}$ by 2008 . The overall increase in methane emission from all the livestock is $20 \%$ from $81.83 \mathrm{Gg}$ in $1980-98.76 \mathrm{Gg}$ in 2008 . With the aggressive drive of government to boost cattle and goat production, there is the likelihood of an increase in methane emission in the future and mitigation options will have to be applied.
\end{abstract}

Key words: Enteric fermentation, manure management, surface temperature, uncontrolled release, microbial activities, National Boer Breeding Centre (NBBC)

\section{INTRODUCTION}

The world is experiencing an unprecedented rise in surface temperature (Ominski and Wittenberg, 2004; Petersen and Ambus, 2006 Kaufmann et al., 2006; Smith et al., 2008; Clark and Huybers, 2009; Domingues et al., 2008; Milne et al., 2009, Trenberth, 2010). This rise is attributed to the increased rate of emission of greenhouse gases into the atmosphere and is said to be caused by the activities of human beings, hence the anthropogenic nature of the problem. Six gases have been identified as constituting the greenhouse gases. Chief among the greenhouse gases being touted as responsible for the rise in global surface temperature are carbon dioxide and methane with trace amounts of other gases (Hansen et al., 2006; 2007). The devastating effects of this temperature rise on human beings and the environment have been extensively reported (Calabro, 2009).
Methane has been identified as a significant contributor to global warming (Xiaoli et al., 2010). It is second to carbon dioxide in contribution to global warming and is said to be $15-20 \%$ of all greenhouse gas emissions (Peterson et al., 2010; Rawat et al., 2007; Lassey, 2008) put it at $12-7 \%$. Methane is said to be explosive when it is present in the air in concentrations between 5-15\% (Huang and He, 2008) and has a global warming potential of 21 (IPCC, 1997, Talyan et al., 2007). For the past 300 years atmospheric methane has increased by about $150 \%$ (Iqbal et al., 2008) and its atmospheric concentration has nearly tripled since preindustrial times (Houghton et al., 2001). Methane is emitted from various man-made and natural sources. The man-made (anthropogenic) sources include Municipal Solid Wastes (MSW) landfills (Machado et al., 2009), rice paddies (Yang et al., 2009; Basse et al., 2009; Zhang et al., 2009), coal mining (Luo and Dai, 2009; Torano et al., 2009), oil and gas drilling and processing (Harrison et al., 1997; Kirchgessner et al.,

Corresponding Author: Zainura Zainon Noor, Department of Chemical Engineering, Faculty of Chemical Engineering,

University Technology Malaysia, 81310 Skudai, Johor Bahru, Malaysia 
1997), cattle ranching (Kebreab et al., 2008), manure (Sommer et al., 2004), agricultural products (Bauer et al., 2009; Wang et al., 2009), anaerobic wastewater treatment plants (Shahabadi et al., 2010) and rising main sewers (Guisasola et al., 2009).

Concerns about the devastating effects of uncontrolled release of hydrocarbons in gaseous forms on ozone depletion and global warming have warranted investigation into animal waste production systems (Dong et al., 2011; Masse et al., 2011). A significant source of atmospheric methane is from animal husbandry (Lascano and Cárdenas, 2010; Nusbaum, 2010). The emission of methane by livestock is part of their natural digestive processes and is produced in the rumen of livestock due to the methanogens found in the reticulo-rumen and large intestine of the livestock (Alemu et al., 2011). The gastrointestinal of all animals generate some microbial activities that lead to the production of gases which are combustible. This microbial activity is very extensive in ruminants (Alemu et al., 2011). Globally, methane emission from ruminants is said to be $15 \%$ of global production (Takahashi, 2011).

The current method in animal husbandry is either to increase the productivity of the animal through improved nutrition in order to produce less methane per unit of meat or milk or to alter the rumen fermentation process so as to reduce the volume of methane produced (Iqbal et al., 2008). Despite all these efforts, $15 \%$ of global methane emissions come from enteric fermentation by ruminants (Houghton et al., 2001; Takahashi, 2011) gave methane emission breakdown from enteric fermentation as $12 \%$ of global, $19 \%$ of anthropogenic and $36 \%$ of agricultural while Naqvi and Sejian (2011) reported that $18 \%$ of greenhouse gas emission comes from animal husbandry.

The contribution of methane emission from ruminants is becoming alarming as EC, (2010) reported that methane emission from livestock was $83 \%$ of the greenhouse gases emitted within the agricultural sector. Kebreab et al. (2008) posited that $287 \mathrm{~m}$ tonnes of methane is released globally and yearly from anthropogenic sources, of which $50 \%$ is from agriculture and enteric fermentation from ruminants is said to be the largest biogenic source USEPA, 2006. Aluwong et al. (2011) gave global anthropogenic methane emission from enteric fermentation and manure management as $35-40 \%$ of total emission.

Methane emission from ruminants is affected by feed intake level, digestability of feeds, feed processing and addition of lipids (unsaturated fatty acid) (Enishi, 2007). Other factors include the quality of the diet, level of stress the animals undergo and their genetics (Hegarty et al., 2007) as well as feed efficiency (Zhou et al., 2009). Cattle is said to produce between 250-500 1 of methane daily (Johnson and Johnson, 1995) while it is said to lose $2-15 \%$ of its ingested energy as eructated methane (Giger-Reverdin and Sauvant, 1998). This loss serves two purposes: lower emission of methane leads to a lowering of greenhouse gas concentration in the atmosphere and increased efficiency in livestock production leads to increased revenue for livestock farmers (Giger-Reverdin and Sauvant, 1998). Cattle and buffaloes contribute about $84 \%$ of animal methane that is produced enterically (Johnson and Ward, 1996) because of their huge body sizes, large appetites and their rumens having extensive enteric fermentation.

Livestock practices in Malaysia: The Malaysian government has initiated strategies that will make agriculture the third machine of economic growth. This effort was highlighted in the ninth Malaysian Plan. To achieve this objective, various forms of support and schemes that will encourage investments have been provided. Some of these attractive incentives provided by government include the setting up of some financial institutions specifically entrusted with the provision of capital facilities for interested investors. These institutions include Bank Pertanian Malaysia (Agrobank Malaysia). The bank is responsible for organising, providing, supervising and coordinating credit facilities for agriculture in Malaysia. Agrobank Malaysia offers financing packages to develop the agricultural, livestock and fishery sectors in Malaysia. Others are Bank Pembangunan dan Infrastruktur and Professional Services Export Fund. The government has also formulated legislations that relate to agriculture and agro-based industries. These legislations are meant to regulate activities in fisheries, livestock and food processing and also include activities like animal farming, animal health, slaughtering, processing and marketing. Through the Department of Veterinary Services, government issues licences and permits that relate to the importation of animals into Malaysia as livestock or pets.

Under the National Meat Policy (ruminant sector), Malaysia aims to increase cows and buffaloes from the present 1.0-1.6 $\mathrm{m}$ in 2015. This will increase Malaysia's self-sufficiency in meat products to $40 \%$ from the present $25 \%$. The plan also wishes to increase the stock of goats from the present $9-35 \%$ by 2015 necessitating an increase of the goat population to 1,500,000 MAHA, 2008. It has also been reported (Boo, 2010) that a unit in the Federal Land Development Authority (FELDA) is going into a joint venture to invest RM688 m on livestock projects in its palm oil estates at Kuala Lumpur, Penang, Johor and Sabah.

Another area of government intervention is the Malaysian Goat Industry Development Programme, a bilateral cooperation with Western Australia, in the areas of marketing, production and support services. 
The government has also established the National Boer Breeding Centre (NBBC) which is expected to be the catalyst for the development of the goats in the form of production of quality boer breeders. The aim is to produce 6,000 and 1,200 heads of female and male breeders yearly respectively MAHA, 2008. The East Coast Economic Region (ECER), whose aim is the development of cattle and goat breeding for the states of Kelantan, Pahang, Terengganu and the district of Mersing in Johor MAHA, 2008.

In addition to all these is the proposed use of about $2 \mathrm{~m}$ hectare of oil palm plantation for cattle rearing as a means of optimizing land use and to increase breeding stock MAHA, 2008.

\section{MATERIALS AND METHODS}

Methane emissions estimation from livestock: Estimation of methane emissions from livestock was based on the multiplication of the heads of the livestock by emission factors provided by IPCC (1997). This estimation is carried out at the Tier 1 and Tier 2 levels. The Tier 1 method uses default emission factors and hence only the livestock population data are required for estimation. It is suitable for most animal species in countries like Malaysia where enhanced characterization data are not available. The Tier 1 method can be applied for the livestock except cattle where Tier 2 is recommended by IPCC (1997). Some default values for emission from enteric fermentation and manure management are summarized in Table 1 (IPCC, 1997).

Emission data for the livestock was obtained from the Department of Statistics and Department of Veterinary Services of the Ministry of Agriculture and Agro-based Industries. The estimation distinguished between enteric fermentation and manure management. Methane emissions were separately calculated for sub-categories of cattle, buffalo, sheep, goats, horses, pigs and poultry. Since Malaysia currently imports most of the livestock feed concentrate, changes in emission due to change in diet will not be captured in enteric fermentation calculation.

Methane emissions from enteric fermentation is expressed as shown in Eq. 1 (IPCC, 1997):

$\mathrm{CH}$ 4 Enteric $=\sum \frac{(\mathrm{EF}(\mathrm{T}), \mathrm{N}(\mathrm{T}))}{10^{6}}$

Table 1:Emission factors for enteric fermentation and manure management

\begin{tabular}{llr}
\hline Livestock & $\begin{array}{l}\text { Enteric } \\
\text { fermentation }\end{array}$ & $\begin{array}{l}\text { Emission } \\
\text { management }\end{array}$ \\
\hline Cattle-Dairy & 68.0 & 31.00 \\
Others & 47.0 & 1.00 \\
Buffalo & 55.0 & 2.00 \\
Sheep & 5.00 & 0.20 \\
Goats & 5.00 & 0.22 \\
Pigs & 1.00 & 7.00 \\
Horses & 180 & 2.19 \\
Poultry & 0.02 & 0.02 \\
\hline
\end{tabular}

where, methane emission is in $\mathrm{Gg} /$ year:

$\mathrm{EF}_{(\mathrm{T})}=$ Emission factor for the defined livestock population $(\mathrm{kg} / \mathrm{head} /$ year $)$

$\mathrm{N}_{(\mathrm{T})}=$ Number of head of livestock species $\mathrm{T}$ in country

$\mathrm{T} \quad=$ Species of livestock

For cattle, where Tier 2 is recommended, the emission factor from enteric fermentation is given by Eq. 2 (IPCC, 1997):

$\mathrm{EF}=\frac{\mathrm{CE}\left(\frac{\mathrm{Y}_{\mathrm{m}}}{100}\right) 365}{55.65}$

where:

$\mathrm{EF}=$ Emission factor $(\mathrm{kg} / \mathrm{head} /$ year $)$ :

$\mathrm{GE}=$ Gross energy intake (MJ/head/day)

$\mathrm{Y}_{\mathrm{m}}=$ Methane conversion factor, percent of gross energy in feed converted to methane $=$ $6.5 \pm 1.0 \%$ for cattle $55.65=$ Energy content of methane $(\mathrm{MJ} / \mathrm{kg} \mathrm{CH})_{4}$

Methane estimation from manure management is given by Eq. 3:

$\mathrm{CH}$

4 manure $=\sum \frac{(\mathrm{EF}(\mathrm{T}), \mathrm{N}(\mathrm{T}))}{10^{6}}$

where:

$\mathrm{CH}_{4 \text { Manure }}=$ Methane emissions from manure management $\left(\mathrm{Gg} \mathrm{CH}_{4} /\right.$ year $)$

$\mathrm{EF}_{(\mathrm{T})}=$ Emission factor for a defined livestock population (kg/head/ day)

$\mathrm{N}_{(\mathrm{T})} \quad=$ Number of head of livestock species $\mathrm{T}$ in country

$\mathrm{T}=$ Species of livestock

The total methane emission is the sum of the emission from enteric fermentation and manure management for each category of livestock.

\section{RESULTS AND DISCUSSION}

Results: Methane emissions from the animals in 1980 and 2008 are provided in Table 2.

Table 2: Methane emissions in 1980 and 2008

\begin{tabular}{lrrrrrr}
\hline & \multicolumn{3}{c}{1980} & & & \multicolumn{2}{l}{2008} \\
& \multicolumn{1}{c}{ EF } & \multicolumn{1}{c}{ MM } & \multicolumn{1}{c}{ Total } & \multicolumn{1}{c}{ EF } & \multicolumn{1}{c}{ MM } & Total \\
\hline Cattle & 30.83 & 14.84 & 45.61 & 44.24 & 21.00 & 65.24 \\
Buffalo & 17.12 & 1.43 & 18.55 & 7.86 & 0.66 & 8.52 \\
Sheep & 0.60 & 0.03 & 0.63 & 0.31 & 0.01 & 0.32 \\
Goats & 1.71 & 0.08 & 1.79 & 1.43 & 0.03 & 1.49 \\
Horses & 0.09 & 0.01 & 0.10 & 0.13 & 0.01 & 0.14 \\
Pigs & 12.86 & 1.84 & 14.70 & 13.03 & 1.90 & 14.93 \\
Poultry & 1.16 & 1.02 & 2.18 & 4.37 & 3.80 & 8.17 \\
\hline
\end{tabular}




\section{Discussion of Results:}

Emissions from cattle: Figure 1 shows methane emission from cattle. Overall emission has risen by $44 \%$ between 1980 and 2008 from $45.61 \mathrm{Gg}$ in 1980 to $65.57 \mathrm{Gg}$ in 2008. While emissions from manure management marginally increased from $14.84 \mathrm{Gg}$ in 1980-21 Gg in 2007, those of enteric fermentation rose from $30.78-44.24 \mathrm{Gg}$ in the same period. As at now Malaysia cattle production of 790,000 is just $20 \%$ of total local demand (Latif and Mamat, 2002) with the bulk of the balance being imported from India due to competitive pricing. If the objective of the government is realized and cattle production increases there is a very high tendency for the emission of methane to more than double the present level unless serious mitigation measures are adopted.

Emissions from buffalo: Emissions from buffalo are shown id Fig. 2. There is a sharp reduction (54\%) in methane emission from the 1980 level of $17.12-7.86 \mathrm{Gg}$ in 2008 with emission from manure management remaining below $1.5 \mathrm{Gg}$. This is so because the stock of buffalo has been on the decline since 1980 when the stock was 285,339 whereas the stock by the end of 2008 was 131,000 . The total present stock of cattle and buffalo is about $1.0 \mathrm{~m}$ and this value is projected to be $1.5 \mathrm{~m}$ by 2015 although the focus of government is to increase the stock of cattle to the detriment of the other livestock. This expected increase in stock population will be accompanied by a proportional increase in methane emission.

Emissions from sheep: Emissions from sheep rose by $350 \%$ from $0.32 \mathrm{Gg}$ in 1980 and peaked at $1.44 \mathrm{Gg}$ in 1992 and dropped by $56 \%$ to the present level of 0.63 $\mathrm{Gg}$ in 2008 Fig. 3. The emission from sheep has been consistent for almost a decade now indicating that the stock of sheep has been steady and almost the same for the last few years since 2001. Emission from manure management has been almost non-existent as the highest emission was $0.06 \mathrm{Gg}$ in 1992.

Emissions from goats Figure 4 shows methane emission from goats and it is not following any pattern. It has shown fluctuating tendencies but has been steady in the last six years starting from 2005. Emission in 1980 was $1.8 \mathrm{Gg}$ and reached its peak a year later at $1.9 \mathrm{Gg}$. Since then the emission of methane from goats has been swinging up and down with the lowest value of $1.22 \mathrm{Gg}$ recorded in the year 2000. As with sheep, emissions from manure management have been virtually nil with the bulk of emissions coming from enteric fermentation.

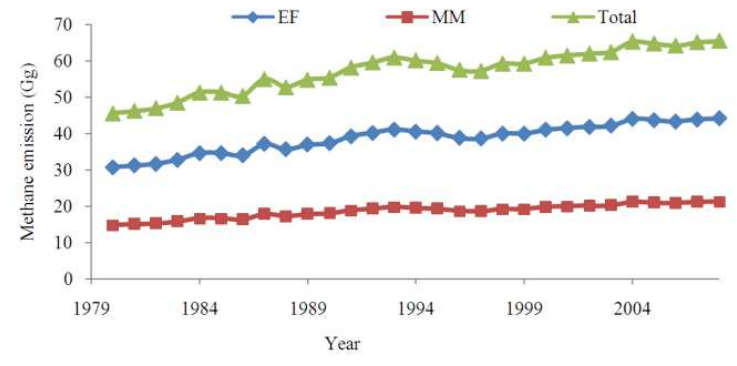

Fig. 1: Methane emissions from cattle

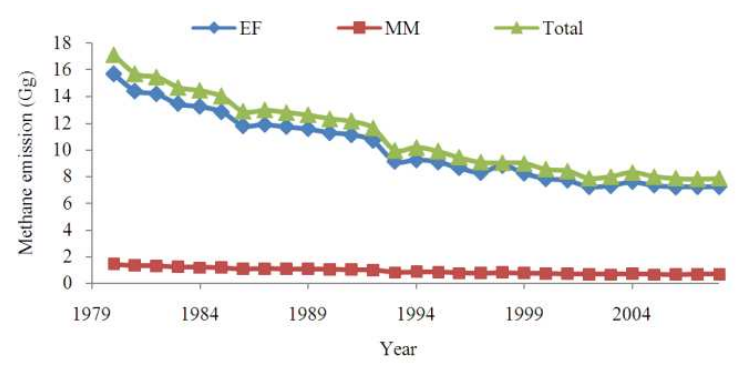

Fig. 2: Methane emissions from buffaloes

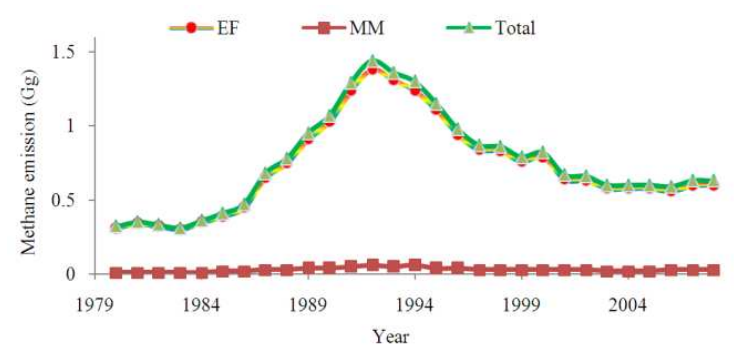

Fig. 3: Methane emission from sheep

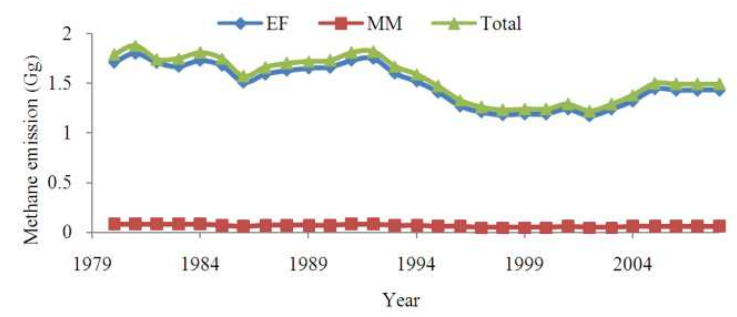

Fig. 4: Methane emission from goats

The lack of any appreciable increase in methane emission from goats might not be unconnected with government policy to focus its attention on increasing the stock of cattle. This apparent stagnation is curious bearing in mind the drive of government to boost the production of goats. 


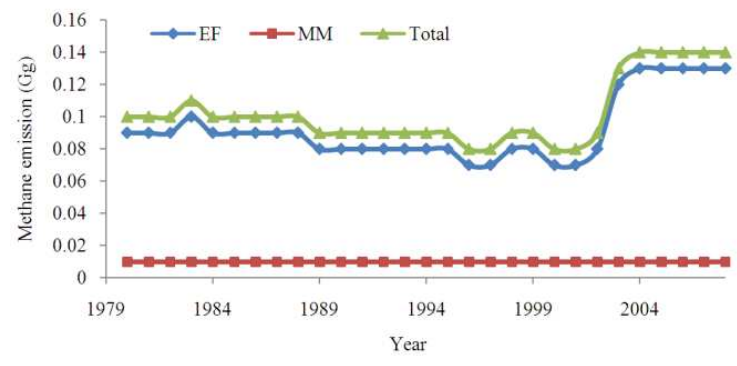

Fig. 5: Methane emission from horses

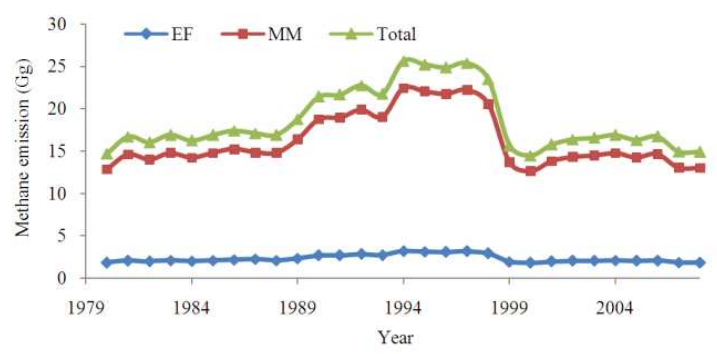

Fig. 6: Methane emission from pigs

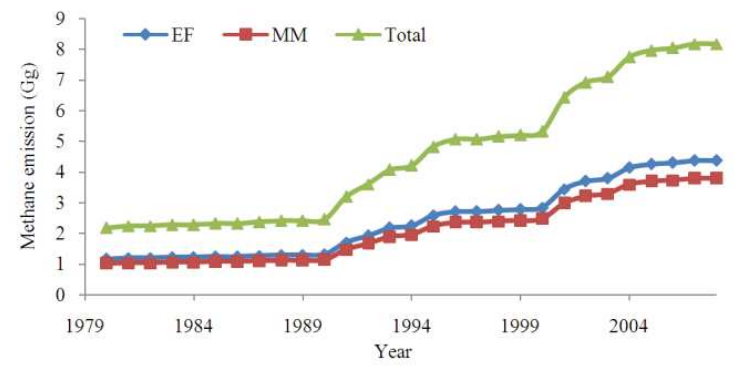

Fig. 7: Methane emission from poultry

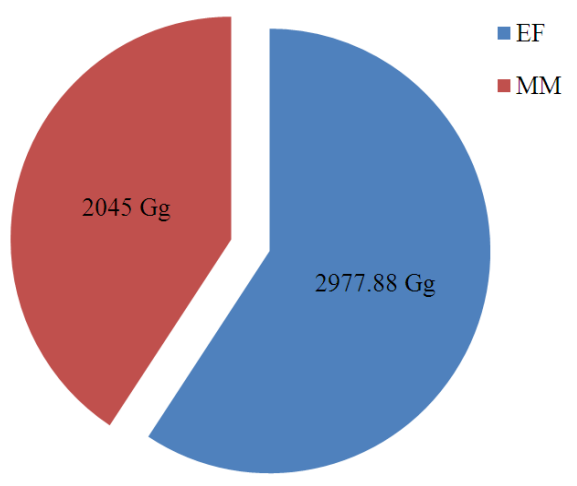

Fig. 8: Total missions from enteric fermentation and manure management
Emissions from horses: The emissions of methane from horses are shown in Fig. 5. The emission trend has been consistent except in the last five years (from 2004) when emission has been the same at $0.14 \mathrm{Gg}$. Emissions from manure management has been consistent all through at $0.01 \mathrm{Gg}$. The increase in emission noticed in the last few years was as a result of sudden increase in the stock of horses from 4000-45007000 since 2004 (a 75\% increase), maybe an indication of affluence and a strong economy. Horses are used by the royal families and some affluent personalities in the society. Overall the emission of methane from horses, which has never gone beyond $0.14 \mathrm{Gg}$, is quite negligible when compared to the other ruminants.

Emissions from pigs: Figure 6 shows methane emission from pigs in Malaysia. Enteric methane emission from pigs is not as pronounced as with the other ruminants because they are monogastric. Nonetheless, emissions from pigs rose by $74 \%$ to a peak value of $25.6 \mathrm{Gg}$ in 1994 from the 1980 value of $14.7 \mathrm{Gg}$. The emission then dropped by $42-14.9 \mathrm{Gg}$ in 2008. There was a sharp drop in emission between 1998 and 1999 when the stock level dropped from $2.9-1.9 \mathrm{~m}$. Since then emission has been almost steady in the last decade while government is encouraging the rearing of cattle instead of pigs. Being an Islamic country Malaysia has found it extremely difficult and near impossible to stop the consumption of pork which has found favor with the Chinese population.

Emissions from poultry: Figure 7 shows methane emission from poultry. This is the fastest growing of all as the stock of poultry rose from $51 \mathrm{~m}$ in 1980 to the present value of $190 \mathrm{~m}$, an increase of $274 \%$. Hence emission also rose from $2.18 \mathrm{Gg}$ in 1980 to the present $8.17 \mathrm{Gg}$ in 2008 . There are indications that this will still continue to rise in the future. Both enteric fermentation and manure management have almost equal contribution to the emission. Because of the exportdriven and thriving poultry industry, there is all possibility that this increasing trend will continue.

Overall emission: When all the emissions are summed up the overall emissions are shown in Fig. 8. Emission from manure management peaked at $45 \mathrm{Gg}$ in 1994 whereas the highest emission from enteric fermentation was $60 \mathrm{Gg}$ in 2004. The overall picture that is emerging is that emission from livestock is hovering around 100 $\mathrm{Gg}$. This value will rise when all the efforts of the Malaysian government to increase livestock production begin to yield dividend. 
Mitigation options: Enteric methane emissions are said to be more amenable to mitigation (Aluwong et al., 2011). Methane reduction strategies have been grouped into three which are management (DeRamus et al., 2003), nutritional (Lovett et al., 2005) and advanced biotechnology (Sejian et al., 2011). There have been many reported cases of methane emission reductions after modification of the dietary feed (Beauchemin et al., 2008; Martin et al., 2009; Shibata and Terada, 2010) while alteration of the fermentation process of the rumen is another option (Christopherson et al., 2008; Iqbal et al., 2008). Land use change is another effective way of emission reduction (Vellinga and Hoving, 2011). The proposed integrated use of palm oil mill plantation to rear cattle, improved cropland and grazing land management and selection of grasses with high concentration of water-soluble carbohydrates, forage legume with secondary metabolites like tannins (Lascano and Cardenes, 2010) will reduce methane emissions. High digestability of pasture for grazing is another option to consider (Hart et al., 2009).

\section{CONCLUSION}

The emission of methane from livestock has stabilized in the past few years. This is expected to rise with the aggressive nature of government intervention in the agricultural sector with the special emphasis on expansion of cattle and goat population. To stem this expected increase in methane emission requires the formulation and adaptation of appropriate mitigation measures. The aim of the government to make agriculture the third machine of economic growth, as enshrined in the ninth development plan, points to a massive increase in livestock population and an increasing threat to the environment due to the potential increase in methane emission. This calls for further investigation of the factors affecting enteric fermentation and manure management.

\section{REFERENCES}

Alemu, A.W., J. Dijkstra, A. Bannink, J. France and E. Kebreab, 2011. Rumen stoichiometric models and their contribution and challenges in predicting enteric methane production. Anim. Feed Sci. Technol. 166: 761-778. DOI: 10.1016/j.anifeedsci.2011.04.054

Aluwong, T., P.A. Wuyep and L. Allam, 2011. Livestock-environment interactions: Methane emissions from ruminants. Afr. J. Biotechnol., 10: 1265-1269.
Basse, E.M., J.C. Svenning, J.E. Olesen, F. Besenbacher and J. Læssoe et al., 2009. The 7 Aarhus statements on climate change. Earth Environ. Sci. DOI: 10.1088/1755-1315/8/1/011002

Bauer, A., P. Bosch, A. Friedl and T. Amon, 2009. Analysis of methane potentials of steam-exploded wheat straw and estimation of energy yields of combined ethanol and methane production. $\mathrm{J}$. Biotechnol., 142: 50-55. DOI: 10.1016/j.jbiotec.2009.01.017

Beauchemin, K.A., M. Kreuzer, F. O'mara and T.A. Mcallister, 2008. Nutritional management for enteric methane abatement: A review. Aust. J. Exp. Agric., 48: 21-27. DOI: 10.1071/EA07199

Boo, S.L., 2010. Felda unit to spend RM688m for cattle project. The Malaysian Insider. Kuala Lumpur.

Calabro, P.S., 2009. Greenhouse gas emission from municipal waste management. The role of separate collection. Waste Manage., 29: 2178-2187.

Christopherson, C.T., A.D.G. Wright and P.E. Vercoe, 2008. In vitro methane emission and acetate: Propionate ratio are decreased when artificial stimulation of the rumen wall is combined with increasing grain diets in sheep. J. Anim. Sci., 86: 384-389. DOI: $10.2527 /$ jas.2007-0373

Clark, P.U. and P. Huybers, 2009. Global change: Interglacial and future sea level. Nature, 462: 856857. DOI: $10.1038 / 462856 a$

DeRamus, H.A., T.C. Clement, D.D. Giampola and P.C. Dickison, 2003. Methane emissions of beef cattle on forages: Efficiency of grazing management systems. J. Environ. Qual., 32: 269-277. PMID: 12549566

Domingues, C.M., J.A. Church, N.J. White, P.J. Gleckler and S.E. Wijffels et al., 2008. Improved estimates of upper-ocean warming and multidecadal sea-level rise. Nature. 453: 1090-1093. DOI: $10.1038 /$ nature 07080

Dong, H., Z. Zhu, Z. Zhou, H. Xin and Y. Chen, 2011. Greenhouse gas emissions from swine manure stored at different stack heights. Anim. Feed Sci. Technol. 166: 557-561. DOI: 10.1016/j.anifeedsci.2011.04.039

Enishi, O., 2007. Greenhouse gas emissions caused from livestock in Japan. Proceedings of the 4th Workshop on Greenhouse Gas Inventories in Asia Jakarta, (GGIAJ' 07), National Institute for Environmental Studies, Japan.

EC, 2010. National Inventory Report 1990-2008: Greenhouse Gas Sources and Sinks in Canada. 1st Edn., Environment Canada, Canada, pp: 582. 
Giger-Reverdin, S., D. Sauvant, I. Ledin and P. Morand-Fehr, 1998. Methane production in sheep in relation to concentrate feed composition from bibliographic data. Proceedings of the 8th Seminar of the Sub-Network on Nutrition of the FAOCIHEAM Inter-Regional Cooperative Research and Development Network on Sheep and Goats, Sep. 3-5, Gignon, France, pp: 1022-1379.

Guisasola, A., K.R. Sharma, J. Keller and Z. Yuan, 2009. Development of a model for assessing methane formation in rising main sewers. Water Res., 43: 2874-2884. DOI: 10.1016/j.watres.2009.03.040

Hansen, J., M. Sato, R. Ruedy, K. Lo and D.W. Lea et al., 2006. Global temperature change. PNAS, 103: 14288-14293. DOI: $10.1073 /$ pnas.0606291103

Hansen, J., M. Sato, P. Kharecha, G. Russell and D.W. Lea et al., 2007. Climate change and trace gases. Phil. Trans. R. Soc. Agric., 365: 1925-1954.

Harrison, M.R., T.M. Shires, J.K. Wessels and R.M. Cowgill, 1997. Methane emissions from the natural gas industry. United States Environmental Protection Agency.

Hart, K.J., P.G. Martin, P.A. Foley, D.A. Kenny and T.M. Boland, 2009. Effect of sward dry matter digestibility on methane production, ruminal fermentation and microbial populations of zerograzed beef cattle. J. Anim. Sci., 87: 3342-3350. DOI: $10.2527 /$ jas.2009-1786

Hegarty, R.S., J.P. Goopy, R.M. Herd and B. Mccorkell, 2007. Cattle selected for lower residual feed intake have reduced daily methane production. J. Anim. Sci., 85: 1479-1486. DOI: 10.2527/jas.2006-236

Huang, Y. and Q. He, 2008. Study on the status of output and utilization of landfill gas in China. Tibet University, Linzhi.

Houghton, J.T., Y. Ding, D.J. Griggs, M. Noguer and P.J.V.D. Winden et al., 2001. Climate Change 2001: The Scientific Basis. Contribution of Working Group 1 to the Third Assessment report of the Intergovernmental Panel on Climate Change. Int. J. Epidemiol., 32: 321-321. DOI: 10.1093/ije/dyg059

IPCC, 1997. IPCC guidelines for national greenhouse gas inventories. 1st Edn., IPCC WGI Technical Support Unit, Paris, ISBN-10: 9264155783, pp: 950.

Iqbal, M.F., Y.F. Cheng, W.Y. Zhu and B. Zeshan, 2008. Mitigation of ruminant methane production: current strategies, constraints and future options. World J. Microbiol. Biotechnol., 24: 2747-2755. DOI: $10.1007 / \mathrm{s} 11274-008-9819-\mathrm{y}$
Johnson, K.A. and D.E. Johnson, 1995. Methane emissions from cattle. J. Anim. Sci., 73: 24832492.

Johnson, D.E. and G.M. Ward, 1996. Estimates of animal methane emissions. Environ. Monit. Assess., 42: 133-141. DOI: 10.1007/BF00394046

Kaufmann, R.K., H. Kauppi and J.H. Stock, 2006. Emissions, Concentrations, and Temperature: A Time Series Analysis. Clim. Change, 77: 249-278. DOI: 10.1007/s10584-006-9062-1

Kebreab, E., K.A. Johnson, S.L. Archibeque, D. Pape and T. Wirth, 2008. Model for estimating enteric methane emissions from United States dairy and feedlot cattle. J. Anim. Sci., 86: 2738-2748. DOI: 10.2527/jas.2008-0960

Kirchgessner, D.A., R.A. Lott, R.M. Cowgill, M.R. Harrison and T.M. Shires, 1997. Estimate of methane emissions from the U.S. natural gas industry. Chemosphere, 35: 1365-1390. DOI: 10.1016/S0045-6535(97)00236-1

Lascano, C.E. and E. Cardenas, 2010. Alternatives for methane emission mitigation in livestock systems. R. Bras. Zootec., 39: 175-182. DOI: 10.1590/S1516-35982010001300020

Lassey, K.R., 2008. Livestock methane emission and its perspective in the global methane cycle. Aust. J. Exp. Agric., 48: 114-118. DOI: 10.1071/EA07220

Latif, J. and M.N. Mamat, 2002. A financial study of cattle integration in oil palm plantations. Oil Palm Econ. J., 2: 34-44.

Lovett, D.K., L.J. Stack, S. Lovell, J. Callan and B. Flynn et al., 2005. Manipulating enteric methane emissions and animal performance of late-lactation dairy cows through concentrate supplementation at pasture. J. Dairy Sci., 88: 2836-2842. DOI: 10.3168/jds.S0022-0302(05)72964-7

Luo, D. and Y. Dai, 2009. Economic evaluation of coalbed methane production in China. Energy Policy, 37: 3883-3889. DOI: 10.1016/j.enpol.2009.06.049

Machado, S.L., M.F. Carvalho, J.P. Gourc, O.M. Vilar and J.C.F. Nascimento, 2009. Methane generation in tropical landfills: Simplified methods and field results. Waste Manage., 29: 153-161. DOI: 10.1016/j.wasman.2008.02.017

Martin, C., M. Doreau and D.P. Morgavi, 2009. Methane mitigation in ruminants: from rumen microbes to the animal. Proceedings of the Livestock and Global Climate Change Conference, May 17-20, Hammamet, Tunisia, pp: 1-16. 
Masse, D.I., G. Talbot and Y. Gilbert, 2011. On farm biogas production: A method to reduce GHG emissions and develop more sustainable livestock operations. Anim. Feed Sci. Technol. 166: 436445. DOI: 10.1016/j.anifeedsci.2011.04.075

Milne, G.A., W.R. Gehrels, C.W. Hughes and M.E. Tamisiea, 2009. Identifying the causes of sea-level change. Nature Geosci. 2: 471-478. DOI: 10.1038/ngeo544

Naqvi, S.M.K. and V. Sejian, 2011. Global climate change: Role of livestock. Asian J. Agric. Sci., 3: 19-25.

Nusbaum, N.J., 2010. Dairy livestock methane remediation and global warming. J. Commun. Health, 35: 500-502. DOI: 10.1007/s10900-0109219-8

Ominski, K.H. and K.M. Wittenberg, 2004. Strategies for reducing enteric methane emissions in foragebased beef production systems. University of Alberta.

Petersen, S.O. and P. Ambus, 2006. Methane oxidation in pig and cattle slurry storages and effects of surface crust moisture and methane availability. Nutr. Cycl. Agroecosyst., 74: 1-11. DOI: 10.1007/s10705-005-3822-6

Peterson, C., C. Barrera, Z. Azizova, 2010. Waste and the World Bank. PennWell Corporation.

Rawat, M., U.K. Singh, A.K. Mishra and V. Subramanian, 2007. Methane emission and heavy metals quantification from selected landfill areas in India. Monit. Assess., 137: 67-74. DOI: 10.1007/s10661-007-9729-8

Sejian, V., R. Lal, J. Lakritz and T. Ezeji, 2011. Measurement and prediction of enteric methane emission. Int. J. Biometeorol., 55: 1-16. DOI: 10.1007/s00484-010-0356-7

Shahabadi, M.B., L. Yerushalmi and F. Haghighat, 2010. Estimation of greenhouse gas generation in wastewater treatment plants-Model development and application. Chemosphere, 78: 1085-1092. DOI: 10.1016/j.chemosphere.2009.12.044

Shibata, M. and F. Terada, 2010. Factors affecting methane production and mitigation in ruminants. Anim. Sci. J., 81: 2-10. DOI: 10.1111/j.17400929.2009.00687.x

Smith, P., D. Martino, Z. Cai, D. Gwary and H. Janzen et al., 2008. Greenhouse gas mitigation in agriculture. Phil. Trans. R. Soc. London, Ser. B. 363: 789-813. DOI: 10.1098/rstb.2007.2184
Sommer, S.G., S.M. Mcginn, X. Hao and F.J. Larney, 2004. Techniques for measuring gas emissions from a composting stockpile of cattle manure. Atmos. Environ., 38: 4643-4652. DOI: 10.1016/j.atmosenv.2004.05.014

Takahashi, J., 2011. Some prophylactic options to mitigate methane emission from animal agriculture in Japan. Asian-Aust. J. Anim. Sci., 24: 285-294.

Talyan, V., R.P. Dahiya, S. Anand and T.R. Sreekrishnan, 2007. Quantification of methane emission from municipal solid waste disposal in Delhi. Resour. Conserv. Recycl., 50: 240-259. DOI: 10.1016/j.resconrec.2006.06.002

Torano, J., S. Torno, M. Menendez, M. Gent and J. Velasco, 2009. Models of methane behaviour in auxiliary ventilation of underground coal mining. Int. J. Coal Geol., 80: 35-43. DOI: 10.1016/j.coal.2009.07.008

Trenberth, K.E., 2010. Global change: The ocean is warming, isn't it? Nature, 465: 304-304. DOI: $10.1038 / 465304 \mathrm{a}$

Vellinga, T.V. and I.E. Hoving, 2011. Maize silage for dairy cows: mitigation of methane emissions can be offset by land use change. Nutr. Cycling Agroecosyst. 89: 413-426. DOI: 10.1007/s10705010-9405-1

Wang, S., X. Yang, X. Lin, Y. Hu and C. Luo et al., 2009. Methane emission by plant communities in an alpine meadow on the Qinghai-Tibetan Plateau: A new experimental study of alpine meadows and oat pasture. Biol. Lett., 5: 535-538. DOI: 10.1098/rsbl.2009.0123

Xiaoli, C., L. Ziyang, T. Shimaoka, H. Nakayama and Z. Ying et al., 2010. Characteristics of environmental factors and their effects on $\mathrm{CH}_{4}$ and $\mathrm{CO}_{2}$ emissions from a closed landfill: $\mathrm{An}$ ecological case study of Shanghai. Waste Manage., 30: 446-451. DOI: 10.1016/j.wasman.2009.09.047

Yang, S.S., C.M. Lai, H.L. Chang, E.H. Chang and C.B. Wei, 2009. Estimation of methane and nitrous oxide emissions from paddy fields in Taiwan. Renew. Energy, 34: 1916-1922. DOI: 10.1016/j.renene.2008.12.016

Zhang, L., D. Yu, X. Shi, D.C. Weindorf and L. Zhao et al., 2009. Simulation of global warming potential (GWP) from rice fields in the Tai-Lake region, China by coupling $1: 50,000$ soil database with DNDC model. Atmos. Environ., 43: 2737-2746. DOI: 10.1016/j.atmosenv.2009.02.051

Zhou, M., E. Hernandez-Sanabria and L.L. Guan, 2009. Assessment of the microbial ecology of ruminal methanogens in cattle with different feed efficiencies. Applied Environ. Microbiol., 75: 6524-6533. DOI: 10.1128/AEM.02815-08 